Article

\title{
Worldview Analysis in a Comparative Context: Fishing for Data in Muddy Waters
}

\section{Lucas F. Johnston}

Department for the Study of Religions and Environmental Program, Wake Forest University, 3400 Wake Forest Drive, Winston-Salem, NC 27109, USA; johnstlf@wfu.edu

Received: 20 June 2018; Accepted: 22 August 2018; Published: 3 September 2018

check for updates

\begin{abstract}
Drawing on the five-fold revision of the concept of "worldview" offered by the issue editors, I investigate whether some nonreligious modes of cultural production might be profitably investigated using such a typology. In my comparative study of religious and secular sustainability-oriented social movements I offered skeletal definitions of the categories "religion" and "sustainability," and suggested ways in which public deployments of such terms might offer fertile ground for collaboration between individuals and groups with different value sets. In more recent work among particular rock music and festival scenes, I have found it necessary to offer a dramatically different understanding of the category "religion." In a sort of thought experiment, I imagine whether the revised concept of "worldview" might be applicable, and indeed whether it offers some advantage over the category "religion." My conclusions are that in general, in some cases the category of worldview may have some advantages, but it may also gloss over or ignore important cultural contestations over terms such as religion, and at best underplay important affective activators of belonging and identity. The notion of "ways of life," or "lifeways" may offer a term which avoids some ethnocentric impositions, but would require greater elaboration to be broadly useful to ethnographers.
\end{abstract}

Keywords: worldview; religion; sustainability; jam band

\author{
Strong beliefs \\ Like ideas come to life \\ Turn atoms into rain and stone \\ Sands and tall trees \\ And Maya, she dances \\ She dissolves into the light \\ Illusions of light \\ Oh Maya, she dances
}

—Widespread Panic, "Fishing"1

\section{Religious vs. Nonreligious: What Is at Stake?}

The small enclosure was completely enveloped in blankets and sheets of black plastic to ensure that no light could get into the room, and those gathered sat quietly as the ceremony began. All of those present had purified themselves in the sweat lodge, and the lawonpi ritual was initiated by the

1 This epigraph is drawn from the lyric of a song penned by one of the jambands discussed below. 
elder, accompanied by several other important community members, drumming rhythmically with him and singing. ${ }^{2}$ The elder's voice was audible above the others, first calling, and then conferring with the spirits. The old man wielded a rattle filled with phosphorous, which when it shook generated sharp flashes against the consuming blackness. Then the flashes grew more erratic, first on one side of the room, and quite suddenly appearing on the other side, puzzling many present since the old man could only walk with the assistance of two canes. The elder's later explanation was that at those moments, the rattle was being played by the spirits. Afterward, some participants reported seeing bodily apparitions in the darkened room. One participant reported her terminal cancer went into remission after the ceremony. What accounts for these perceptions of spirit beings, or the healing benefits of such ceremonies?

This is a form of cultural expression that few would deny is religious. But take for example this description of a concert event by the performance artist the Polish Ambassador, that most people would not consider explicitly religious, but which has religion-resembling dimensions and is formative of normative modes of fellow-feeling:

At Beloved Festival this past Sunday, the stage crew brought my performance table out into the center of the dance floor. ${ }^{3}$

For an hour and a half friends, family, and extended tribe made their way around the table and dance floor: smiles beaming, hearts bursting open, tears welling up, people dancing their prayers.

It felt more real, more connected than any performance I've ever played. Fully immersed in the crowd. Fully tapped into the collective movement and consciousness that was that dance floor. It felt like a ceremony, a hive mind movement meditation with a continuous exchange of giving and receiving, both ways by audience and performer. For me, there was no clear separation.

At the end of my set, a flood of tears spilled forth. If I were to put that into words it would go something like this.

I was fully seen, and fully loved by the people surrounding me. There was no part of me that could hide and it felt so good, so real, so healing, and so connected. I beamed unlimited gratitude right back at the people surrounding me, flooding me with love, and it all erupted in tears of joy.

Thank you so much. ${ }^{4}$

The description includes explicit reference to religious elements (i.e., "dancing their prayers") but in a context that would typically be considered secular-a music festival. Certainly there are differences between these instances, but both obviously have what many might refer to as religious dimensions. The co-editors of this special issue have attempted to dodge some of the problems inherent in defining religions in a way that captures such diverse modes of cultural production by employing a definition of "worldviews" or "ways of life" rather than religion, which may extend even to nonreligious cultural formations. Indeed, part of the problem is that such modes of cultural production are often imagined as quasi- or parareligious, which privileges a certain kind of experience as authentically "religious," and others only analogically so.

2 I was present at this event, which is a traditional shamanic ceremony, and in this case was led by a Lakota elder named Floyd "Looks for Buffalo" Hand, who claims to be a full-blooded Oglala Lakota grandson of Big Foot (whose posthumous portrait is the most remembered scene from the massacre at Wounded Knee), and the product of the first planned marriage of the Red Cloud and Crazy Horse Bands (Hand 1998). His birth was supposedly prophesied by previous healers, although like many indigenous leaders today who combine indigenous religions and the Christian traditions that were forced upon them, he has his share of critics. The point here is not to defend him, but rather to note that these ceremonies have deep evolutionary roots, and that for many, they work.

3 See https:/ / belovedfestival.com (accessed 8 June 2018).

4 This was posted on his artist Facebook page on 12 August 2014. 
Both of the cases above implicate affectively-oriented psychological and physiological processes. But tracking the religious dimensions of these movements and putting an analytical finger on them is rather like nailing Jell-O to the wall. The Hindu goddess of illusion invoked in the epigraph, Maya, paired with the practice of fishing, may be an apt metaphor for ethnographic work. Ethnographers plumb for data, but their findings are neither purely a product of their construction, nor are they "authentic" renderings of particular cultural groups. What comes out of the water depends upon the bait you use, and also on which groups (and within those groups which individuals) choose to bite.

In what follows I offer a framework for how we might pursue such a task, fishing for data in a sea of cultural production, much of which is only transiently, or implicitly religious. Specifically, first, I will review my fieldwork among sustainability-oriented social movements, as well as more recent ethnographic work detailing the religious dimensions of social movements commonly referred to as "jambands" - improvisational rock music and festival cultures. To provide a thought experiment drawn from the editors' intention to resuscitate worldviews and ways of life as analytical categories, I ruminate on whether such a typology could provide explanatory power related to the subcultures I have researched.

I found that in some cases, for instance the sustainability-oriented movements recounted below, the concept of worldviews might provide a sort of template for comparing social groups who hold disparate value sets and ways of enacting their identities. Yet, the concept of worldviews proves more problematic if applied to the social movements related to certain music subcultures. It is possible that the term "ways of life" might prove more useful in analyzing such groups. But as I detail below, it requires some elaboration on the differing scales of the communities which provide significant identity foci for individuals. With a few exceptions, religious studies scholars have not adequately attended to the ways in which most people are bricoleurs, cobbling together multiple modes of religious belonging which are highly individualized, but which still promote certain forms of community identity (Taylor 2002; Johnston and Taylor 2016; Harvey 2013), and perhaps this is a starting point for clarifying terminology.

\section{The Religious Dimensions of Nonreligious Phenomena}

Is there an advantage to re-inventing old terms, or is it better to generate new ones? My own research has focused specifically on studying social movements that are not all about religion and which in some cases are not explicitly religious at all, but which nonetheless have significant religious dimensions. I draw on this research in an attempt to consider the merits of the proposed (re)deployment of the term "worldviews," which may better capture the kinds of phenomena I have studied. Importantly, referring to the "religious" dimensions of nonreligious phenomena, I am making a distinction between modes of cultural production many would consider self-evidently "religious" versus those that are supposedly not. For analytical purposes, the title of this section refers to a sort of folk understanding of the term "religion" (Johnson 1993; Benthall 2008, pp. 7-9) and is not meant as a reification of some umbrella category, nor does it represent some latent essentialism that points toward something authentically religious. All deployments of such categories represent the interests of the person or group utilizing them. Such terms permeate everyday life, and individuals and groups need not arrive at a consensus definition before discussing the ways in which they perform religious cultural work (indeed, as I suggest below, Wittgenstein imagined that such fuzzy categories might act as a sort of social therapy).

As a graduate student, I became intensely interested in the concept of sustainability and its cognate sustainable development. I studied the cultural emergence of such terms and social movements associated with them both among explicitly religious and interfaith groups, and in secular contexts. I noted that even among ostensibly secular sustainability-oriented individuals and groups much of the discourse was couched in religious or spiritual terms (i.e., personal epiphanies, conversion moments, or universalized moral precepts). Although such examples were legion, there was as yet no systematic analysis and comparison of the varieties of sustainability-oriented advocacy. In Religion and Sustainability (2013) I defined religion, as Ninian Smart-the scholar who is perhaps most 
responsible for the popularization of the term "worldview" — did (Smart [1973] 2008), by utilizing a "family resemblance" model first pioneered by the philosopher Ludwig (Wittgenstein [1953] 1968). The advantage to such approaches is that it is possible to define or bound a category without naming some substantive essence that must be present to trigger the use of the term. The anthropologist Benson Saler, after reviewing a number of ways in which the category religion might be bounded, suggested that Wittgenstein's family resemblance approach could be fruitfully combined with "prototype theory," in wide use in biology to place plants and animals into appropriate taxa, to generate a robust definitional strategy (Saler 1993). The religion scholar David Chidester made a parallel move away from defining religious essences when he noted that concepts and categories that were not explicitly religious might still perform "religious work" by binding communities of people together, focusing desire, and channeling exchange relations (Chidester 2005, p. 5). Even authentically fake religions, he noted, do important cultural work. ${ }^{6}$ I wanted to use such a broad definition because my aim in that book was to compare explicitly religious, interfaith, and secular sustainability movements, noting the overlaps and divergences in the ways in which they deployed such terminology. These definitional strategies worked quite well when comparing sustainability-oriented social movements, allowing me to perceive spiritual metaphors and tropes, and language related to core values and deep beliefs operative even among secular sustainability advocates. Indeed, the way I imagined the category of religion (detailed below) led me to dismiss the need to differentiate between "religion" and "spirituality," noting that whatever might be classified by my interlocutors as "spiritual" would fall under that broad stipulative definition.

My approach here follows that advocated by the scholar of religions J.Z. Smith, who noted that the primary stock-in-trade of scholars who study religion is the deployment of specific definitional strategies which cast light upon particular cultural phenomena, and comprise the study of religions. Smith influentially argued that "Religion is solely ... created for the scholar's analytic purposes by his imaginative acts of comparison and generalization" (Smith 1982, p. xi). Elsewhere I have argued that the same is true of sustainability (Johnston 2013): it should not be imagined in an essentialist way, as a fixed goal, or endpoint, but as a function of the imaginative acts, interests, and values of the individual or group deploying the term. When individuals or groups utilize the term sustainability, they give a glimpse into their core values, those things (whether they are cultural practices, economic development, social equity, and so on) that they wish to see persist into the foreseeable future. While I remain interested in sustainability-oriented subcultures, I have extended my analyses to the proliferation of festival and music scenes which traffic in religious and spiritual metaphors, tropes, and imagery, and which channel social interactions in ways that are designed to promote an ethic of fellow-feeling and positivity. But in contrast to the way in which I defined religion above, it quickly became clear to me that participants in these subcultures themselves made explicit what they perceived to be the differences between "religion" and "spirituality."

In an attempt to use categories of analysis that would be understandable to those I wanted to study, I began to differentiate between those who claimed to be religious, and those who claimed to be "post-religious," or even atheist, but who still describe their experiences by deploying concepts and terms which invoke spiritual perceptions, sentiments, and practices. The opening vignettes at least pointed toward this expanded sense of spiritual perception and possibility. But they also highlight the problems

5 The anthropologist Jonathan Benthall made another similar, parallel case in his Returning to Religion (2008), which proposed a theory of a "religious field" which might run from weak to strong, with those in the strong religious field representing something closer to what Saler would consider a "prototype," while those in the weak religious field were social movements or groups which may not have all the trappings of typical or mainstream religions, but which nonetheless have important religious dimensions or elements.

6 Chidester (2005) provided a number of examples, from religions meant to parody institutionalized practices, to those which package the worship of money inside extant religious texts and doctrine. Chidester expanded on his book when he discussed Pastafarianism, the religion of the Flying Spaghetti Monster (Van Horn and Johnston 2007) as a respondent to a panel at the American Academy of Religion in 2007. 
inherent in defining terms like "religion" for an interdisciplinary audience, which I surmise is one of the reasons the editors endeavored to resuscitate the term "worldviews" which, they hope, can be finessed to apply to both religious and nonreligious modes of cultural production. As Saler put it, "if we deem admission to a group (as comprehended by the category religion) [or, worldviews], to be a matter of 'more or less' rather than a matter of 'yes or no,' then an argument can be made for admitting 'secular religions' and 'quasi-religions' as peripheral members" (Saler 2004, p. 230). If, following Chidester and Benthall, it is possible to imagine that there are religious dimensions to modes of cultural production that range from Tupperware parties, to baseball fandom, to live music performances (Chidester 2005; Johnston 2016a), and from religious nongovernmental organizations to social justice organizations (Benthall 2008), then it is possible to imagine an amazing variety of cultural phenomena as deployments of worldviews, even if different elements of their worldviews hold primacy.

For instance, it became clear that for many of my interlocutors, it was the experience of participating in music and festival scenes that became formative for their ethical and (in some cases) "cosmographic formations," a term proposed by the anthropologist and historian Daniel Dubuisson (2003). It could, he believed, be used in place of terms like "religion" or "worldviews," which carried significant cultural baggage related to appropriation, and in some cases ethnocentric imposition of descriptive terms. Like this special issue's editors, Dubuisson imagined his work as confronting (or perhaps sidestepping) some of the problems inherent in defining categories such as "religion." His formulation of cosmographic formations, however, strikes some as unwieldy and potentially opaque. The question, then, is whether the advantage lies in deploying some entirely new formulation (such as Dubuisson's), or whether there is some advantage to reinventing old terms, such as "worldviews". Historically, the individual "experience" was often posited as the source of religiosity (James [1902] 2002; Eliade 1959; Müller [1870] 2002; Otto 1958). Attributing explanatory priority to private experience, however, has thankfully also been problematized (Taves 2009; Arnal and McCutcheon 2013). If, then, we imagine that such experience consists of public instantiations of values, the channeling of exchange relations in particular directions, and the creation of community coherence, then in Chidester's terms, such experiences are doing public religious work (Chidester 2005, p. 18). Indeed, it may necessitate a re-formulation of worldviews to accord with the notion that they are not primarily rational constructs, but more often experientially-grounded, affectively-rich formulations often based in evolutionarily deep human proclivities for empathy and fellow-feeling. This points toward the importance of exercising phrases such as "ways of life," either in place of, or in addition to "worldviews," for balance. Moreover, it is perhaps the case that the ways in which groups-not uniformly but at least at the level of sociological analysis-prioritize the five elements of worldviews elaborated by the issue editors, may be crucially important to ethnographic researchers.

\section{The Religious Dimensions of Sustainability-Oriented Movements, and the Therapeutic Value of Worldview Analysis}

Hence, provided that old terms can be deployed in productive ways, there may be no need to jettison them. Religion, like sustainability, is what Wittgenstein referred to as a "concept-word," a term that refers to a category of things that represent a "family" (Saler 1993, p. 197; Benthall 2010, pp. 46-80). For Wittgenstein, concept words are important because their flexibility allows for their deployment in "language games," which prevent the "freezing" of language by facilitating new relationships between such concept words (Wittgenstein 2001 [1953], p. 109). Language games are tools for interpretive interventions-they represent possibilities for adaptive behaviors to the worlds humans find themselves thrown into. Broad categories can act as a sort of social "therapy" precisely because of the variety of ways in which they might be imagined or construed. For Wittgenstein, this helped to clarify the problems with the disease of language. But if "religion" is such a category, then each deployment of the term acts as a window into the core commitments, values, and beliefs of the individual or community exercising the term. For the ethnographer, such terms are not a glimpse into some essential element or thing that is "religion," "religious," or characteristic of "worldviews." Rather, the data for analysis are the ontologies, normativities, and the other elements 
of worldviews stipulated by the editors' definition, forms of cultural production which are exercised in various and public ways (Von Stuckrad 2007; Johnston 2016b).

Like religion, the concept of sustainability is notoriously slippery. Some define it in terms of sustainable development, which imagines that poverty is the primary problem that must be solved, and that "development" requires increasing economic growth (WCED 1987). Such approaches are endorsed by international bodies, such as the United Nations and the World Bank, and other non-governmental and civil society organizations (Johnston 2013, pp. 48-68). Others have offered counter-hegemonic definitions of the term, which present alternatives to current development practices and socio-political arrangements (Sumner 2005; Hawken 2007). Still others, particularly scientists, might regard sustainability as something best defined by metrics related to biodiversity, or ecosystem services (Patten 2000; Lovejoy 2002). All of these are in some sense problematic. In contrast, I have defined sustainability as a concept word that provides a glimpse into the core values and beliefs of the individuals or group exercising the term. To provide a skeletal definition, sustainability can be imagined as a strategy of socio-ecological adaptation, typically couched in narratives about affective fulfilment (sometimes even including future generations, or other-than-human creatures) (Johnston 2013, p. 25).

I sought to compare the character of sustainability discourse among explicitly religious, interfaith, and secular nongovernmental organizations. To provide texture to the argument, I selected as cases at least one organization in each of those three categories (religious, interfaith, and secular) that operated on a local or national level, and one whose work was international in scope. ${ }^{7}$ It was clear that high level actors in these organizations had different motivations for sustainability activism and advocacy, and characterized it in different ways in the public sphere. All of them, however, trafficked in the language of values, beliefs, and praxis, and given the broad schematic definition above, they were doing religious work.

Often the contributions of religious individuals or groups to sustainability are primarily anecdotes about successful activist campaigns, or analyses of practitioners who hunt down glimmers of green in historical resources (Callicott 1994; Tucker and Williams 1997). ${ }^{8}$ My focus, however, was on the ways in which these various groups cast their identities into the public sphere, and how they engaged in conversation with individuals and organizations who had distinctly different motivations and value sets. From this comparative approach, it was possible to imagine that the real work of sustainability, the path to cultivating diverse, resilient, and adaptive biocultural systems, is the capacity (as individuals or as groups) to engage in dialogue with ethnic, cultural, or ethical "others," placing core values and beliefs on the table for scrutiny. This requires a certain amount of vulnerability, which I have called an ethic of personal risk (Johnston 2014). Such conversations about sustainability (and its many cognates) may have a more important practical function: the inclusion of core (often religious) values in conservation and development debates can facilitate sustainable relationships between people with different values. As the founder of the secular sustainability-oriented organization Natural Capital Solutions, Hunter Lovins told me, "if you look at what's driving unsustainability, it is largely, I think, the absence of these conversations across value structures" (interview, 6 August 2008). In short, it was clear that strategies which focused on the translation of ontologies, normativities, cosmologies, and praxis to others can be particularly important in facilitating communication and cooperation between groups who have distinctly different ideas of what sustainability is, and the pathways by which it can be achieved. But might these case study groups be fruitfully characterized by the five-fold re-conceptualization of worldviews?

7 There were seven case studies in total. Religious organizations included the Northland Church (an evangelical megachurch with approximately 13,000 members), and the Evangelical Environmental Network (EEN). The interfaith cases focused on Interfaith Power and Light (IPL) and the Alliance of Religions and Conservation (ARC). Secular organizations included the Northwest Earth Institute (NWEI), Conservation International (CI), and Natural Capitalism Solutions (NatCap).

8 Callicott's book is not limited to the world religions, but also includes analysis of indigenous cosmologies and ethics. His survey of environmental ethics "from the Mediterranean Basin to the Australian outback" is cited and affirmed in the Series Foreword for volumes on the World Religions and Ecology, published by Harvard's Center for the Study of World Religions. The volume cited here is the first volume of the series. 
A major benefit of the worldviews rubric is that it allows researchers to discern how and why different groups perceive the importance of the various elements. The operative question here, then, is whether there is some benefit to deploying the term "worldviews," as opposed to imagining "religion" as having the same elements (or perhaps more).

For instance, evangelical advocates for "creation care" tend to advocate for sustainability from what ethicists refer to as a theocentric perspective. The prominent evangelical leader Richard Cizik, at a creation care conference in Longwood, FL, opined: "we [evangelical leaders] have to have a cosmocentric worldview—not an anthropocentric worldview" (21 February 2008). He was attempting to decenter humanity, and foreground the biblical narrative that humans ought to be good stewards of creation (Johnston 2013, pp. 119-20). In this narrative, all creatures, their habitats, and indeed the whole creation is created by, and thus deeply ontologically dependent on God. That is, their concern for creation is directly related to their cosmological and ontological presuppositions. Because evangelical theological commitments evolved in a Western Christian, and particularly European Protestant milieu, they reflect some of the epistemological presuppositions characteristic of the emergence of modernity, including a philosophical anthropology in which humans are somehow "above" or superior to other-than-human creatures and habitats. ${ }^{9}$ The axiological precepts which flow from these primary concerns are spelled out in sacred texts, although how they are prioritized, of course, varies greatly. As a result, their praxeology also exhibits wide variance. Some evangelicals perceive that God lavishes riches upon the favored (Johnston and Wall 2014), while others, such as the prominent evangelical preacher Joel Hunter, believe that "he who has a lot of good has someone else's goods" (Johnston 2013, p. 121). ${ }^{10}$ Thus, if we imagine the five-fold definition of worldviews which guided this special issue as comprised of (1) ontology; (2) epistemology; (3) axiology; (4) praxeology; and (5) cosmology, then those who advocate for evangelical creation care might be imagined as prioritizing these elements in the following order: cosmology $\rightarrow$ ontology $\rightarrow$ epistemology $\rightarrow$ axiology $\rightarrow$ praxeology (see Figure 1). ${ }^{11}$

In contrast, when considering the religious dimensions of sustainability, most interfaith work to date has focused on conversation and dialogue, and tends to use as a starting point some sort of common, minimal global standard for environmental care grounded in the world religions (Tucker and Williams 1997, p. xxiv). Even if they were "not looking for a unified worldview or a single global ethic" (Tucker and Williams 1997, p. xxiv), the aim of some scholars was to graft a reverence-for-life-ethic onto existing religious cultural production. Moreover, crucial to such ideas is a "re-evaluation of our place in the cosmos ... [awareness] that human solidarity and kinship with all life is strengthened when we live with reverence for the mystery of being, gratitude for the gift of life, and humility regarding the human place in nature" (Pigem 2007, p. 11). Much of this work presupposed a problematic idealism that religious ideologies were important variables in the quest for environmentally sustainable societies (Tucker and Williams 1997; Tucker and Berthrong 1998; Chapple 2000; Chapple 2002; Hessel and Ruether 2000; Tirosh-Samuelson 2002; Foltz et al. 2003; Grim 2001). One of the most provocative outcomes of such conversations is the Earth Charter, which advanced such a minimum common denominator ethic grounded in a reverence for the planet, its diverse cultures, and other creatures (Taylor 2010, pp. 202-5). Martin Palmer, Secretary-General of the Alliance of Religions and Conservation, however, is critical of the Earth Charter: "I don't know anybody apart from those who promote it who's even heard of it ... What does it do other than state the obvious in a somewhat bland way? People do not do things because they're the same. They do things because they have something distinctive to give" (interview, 28 May 2008). Thus, even if a common

9 For well-known critical histories of such ideas, see Merchant (2008); and Baumann (2014).

10 Dr. Hunter attributed this quote to Augustine, although I have not been able to ascertain where Augustine might have said this.

11 I am grateful to Robin Veldman, who pointed out that while it might be relatively simple to pick out the "primary" element for many constituencies, the prioritization of the following elements may demonstrate some variance, or it may be harder to determine causal influences of one element on others. 
ethic is not prescribed, there are certain attitudes and ethical orientations which precede context specific questions such as "what actions are appropriate?" If we were to characterize these interfaith sustainability-oriented organizations, then we might imagine them as prioritizing the five elements in the following way: axiology $\rightarrow$ cosmology $\rightarrow$ praxeology $\rightarrow$ ontology $\rightarrow$ epistemology. In other words, ethical presuppositions and common cosmological ground (i.e., that all of the heavy elements that comprise organic life are the products of a universal "flaring forth" and evolution) are primary considerations in interfaith conversations-something we all ought to agree upon. What individuals and groups do about it, and how different groups gain knowledge about their worlds (i.e., their epistemologies) are subsidiary concerns (see Figure 1).

The secular sustainability advocates I examined in my research tend to lead with the scientific consensus, and relate that to what we (as a community, society, or nation-state), supposedly, ought to be doing. In this case, action is primary, leading to obvious conclusions about behaviors that can assist in reaching certain goals (for instance, carbon-reduction targets). There is a general awareness that one can advocate for environmental behaviors and sustainable societies from either a biocentric perspective, or a human-centered one. Both approaches, in fact, concur on many of the steps that must be taken to advance toward sustainability (Norton 1994). Most of these advocates admit that the environmental and social problems our societies face are real, and may well even disagree on cosmology, if it is even a consideration. Cosmological constructs, in this case, are often an afterthought, or at best, rendered in relatively vague terms, more metaphorical than literal (as opposed to the explicitly religious groups). It may be possible to characterize some of these groups as prioritizing the elements of worldview this way: praxeology $\rightarrow$ axiology $\rightarrow$ ontology $\rightarrow$ epistemology $\rightarrow$ cosmology (see Figure 1 ).

\begin{tabular}{|c|}
\hline \multicolumn{2}{|l|}{ Categories } \\
\hline (1) Ontology \\
\hline (2) Epistemology \\
\hline (3) Axiology \\
\hline (4) Praxeology \\
\hline (5) Cosmology \\
\hline
\end{tabular}

\begin{tabular}{|l|l|l|}
\hline Evangelical & Interfaith & Secular \\
\hline (5) Cosmology -theocentric & $\begin{array}{l}\text { (3) Axiology-conversation } \\
\text { and dialogue; common } \\
\text { ground }\end{array}$ & $\begin{array}{l}\text { (4) Praxeology-we have } \\
\text { the science, we need people } \\
\text { to enact what we know will } \\
\text { work }\end{array}$ \\
\hline $\begin{array}{l}\text { (1) Ontology-theology of } \\
\text { dependence/Western } \\
\text { conceptions of spirit/ } \\
\text { matter dualism }\end{array}$ & $\begin{array}{l}\text { (4) Praxeology-what should } \\
\text { be do with this common } \\
\text { denominator ethical } \\
\text { understanding? }\end{array}$ & $\begin{array}{l}\text { (3) Axiology-any ethical } \\
\text { stance will concur on basic } \\
\text { principles of what to do: } \\
\text { virtue ethics; deontological } \\
\text { ethics; utilitarian ethics }\end{array}$ \\
\hline $\begin{array}{l}\text { (2) Biblical cosmology- } \\
\text { illustrates human } \\
\text { dependence on a Creator }\end{array}$ & $\begin{array}{l}\text { (5) Cosmologically- } \\
\text { speaking, a common past } \\
\text { (i.e., universe story/big bang) }\end{array}$ & $\begin{array}{l}\text { (1) Ontology-the } \\
\text { problems we face (as a } \\
\text { species, or society) are real }\end{array}$ \\
\hline $\begin{array}{l}\text { (3) Epistemology-the } \\
\text { scriptures spell out the } \\
\text { theological human } \\
\text { exceptionalism }\end{array}$ & $\begin{array}{l}\text { (1) The cosmos or earth as } \\
\text { the ground of being-what is } \\
\text { important }\end{array}$ & $\begin{array}{l}\text { (2) Epistemology-in } \\
\text { many cases secular } \\
\text { organizations can work } \\
\text { with local (indigenous) } \\
\text { knowledge }\end{array}$ \\
\hline $\begin{array}{l}\text { (4) Praxeology-varies by } \\
\text { interpretation }\end{array}$ & $\begin{array}{l}\text { (2) Epistemology -allowing } \\
\text { for indigenous and other } \\
\text { lifeways, but what is } \\
\text { important is common ground }\end{array}$ & $\begin{array}{l}\text { (5) Cosmology-there are } \\
\text { many which can lead to the } \\
\text { axiological/praxeological } \\
\text { elements above }\end{array}$ \\
\hline
\end{tabular}

Figure 1. Worldviews of sustainability-oriented social movements. 


\section{The Emergence of the Jamband Scene}

Expanding the ethnographic gaze beyond sustainability-oriented subcultures to others which, although not explicitly religious, evidence significant spiritual dimensions, another provocative data set emerges. The above sustainability-oriented case studies were conducted at a particular place and time: they are a cross section-a relevant, if static set of studies. While it is possible to see the dynamism of the elements of worldviews in a snapshot of those movements, my more recent ethnographic work has also attempted to discern how and why behaviors and perceptions related to social and environmental issues change over time. Can the revised category worldviews be relevant to other subcultures whose constituents' ontologies, cosmologies, axiologies, and praxeologies, change over time? My most recent research project investigated the religious contours and perceptions related to the environment among participants in jamband concert and festival scenes.

Before we get too far down the road, it is important to clarify two related questions: What is a "jamband," and what is the broader "scene" that such music cultivates? Dean Budnick, founder of jambase.com, Relix magazine, and the Jam Nation radio show (who also happens to hold a PhD in cultural studies from Harvard) is often credited with coining the term in the late 1990s. But as Budnick himself noted, he should be imagined as the popularizer of the term, since it was certainly in wide usage by the time the 1992 Horizons of Rock Developing East Coast (H.O.R.D.E.) tour commenced (Budnick 2003, p. 241). ${ }^{12}$ According to Budnick, the defining feature of jambands was their "musical variegation... [and] a penchant for bending and blending established genres" (Budnick 2003, p. 242). The social historian and lifelong jamband aficionado Peter Connors put it this way: "At the core of all jam bands is a dedication to improvisation as a chance to create a unique, spontaneous, artistic/musical event shared between band and artist. A jam band cannot reach that point without the energy of the audience. Nor can the audience reach it without the band .... That singular, shared musical experience is the beating heart of the jam band scene" (Connors 2013, p. x). ${ }^{13}$ In addition, although most of the bands detailed here did produce studio albums, all of them emphasized live music performance over recorded albums, and among the fans and scene these are the most important aspects of the music (Connors 2013, p. xi).

Even if the term "jamband" came into usage in the 1990s, the roots of such scenes are traceable to forms of cultural experimentation in the mid- to late 1960s. The acclaimed author Ken Kesey and his co-conspirators, who dubbed themselves the Merry Pranksters, engineered new modes of cultural production which flaunted social mores, but also moved away from radical leftist movements in the Bay Area in the 1960s. They adopted a relatively anarchistic back-to-the-land ethos, and a form of interbeing and fellow-feeling grounded in social and musical experimentation. The Acid Tests were the driving force behind this transition: "one of those outrages, one of those scandals, that create a new style or a new world view," as the popular author Tom Wolfe put it (Wolfe 1968, p. 250).

The first of these so-called Acid Tests was held in Soquel, California in 1966, and several more followed. The common features of these early Acid Tests included ingesting lysergic acid diethylamide (LSD), which was then still legal, and experimentation with music, film, and sound. ${ }^{14}$ As Wolfe noted, the psychedelic era and style "came straight out of the Acid Tests in a direct line leading to

12 The H.O.R.D.E. tour was started by the band Blues Traveler, based in the Northeastern U.S. It is important to this story for two reasons: it was the first large-scale festival dedicated specifically to jamband music, and it was one of the first of a new generation of rock music festivals which targeted their marketing products and branding to draw large crowds. The organizers reached out to other groups whose musical styles privileged live performance and improvisation. The other bands who joined them on the tour included Colonel Bruce's Aquarium Rescue Unit, Widespread Panic, Phish, and the Spin Doctors. The lineup shifted over the life of the festival.

13 Here Connors splits the word into "jam bands," another common rendering. I preserved his spelling here, but utilize Budnick's spelling throughout the article outside of quotations.

14 These events typically included live music, but also experimentation with sound and light. During the acid tests, microphones were placed in random places around the room to pick up sounds and conversation and broadcast them into the venue, and tape loops were created and recycled. 
the Trips Festival in January 1966" (Wolfe 1968, p. 250). That festival, held at Longshoreman's Hall in San Francisco, was envisioned as simulating the experience of ingesting LSD, and was an important benchmark, especially among youth subcultures. The event was organized by Ken Kesey and the Merry Pranksters, among them Neal Cassady, the real-life referent for Dean Moriarty, the protagonist of Jack Keroauc's On the Road (Keroauc [1955] 1991). But among the stars of the event was a band that had recently changed their name from the Warlocks to the Grateful Dead. As Wolfe tells it, "the Trips Festival grossed \$12,500 in three days, with almost no overhead, and a new nightclub and dance-hall genre was born. Two weeks later Bill Graham [a promoter] was in business at the Fillmore with a Trips Festival going every weekend and packing them in ... the Haight-Ashbury era began that weekend" (Wolfe 1968, p. 263). The experience, and its accoutrements, were quickly commercialized.

Analysis of the politically focused New Left movement in Berkeley, the more socially concerned hippie movement in San Francisco, and the arguably even more radical countercultures associated with the Acid Tests revealed divergences among these politically efficacious groups, but there were also important overlaps. Most of these movements valorized alternative lifestyles which might include vegetarianism, meditation, alternative living arrangements (such as communal habitation), and a normative commitment to pacifism, or sometimes direct action. Inspirations for these lifeways generally came from non-Abrahamic modes of spirituality. Many young people looked to the East (especially to Buddhism and Daoism), or to indigenous cultures for models of more authentic or desirable ways of life. These were manifestations of what the sociologists Charles Glock and Robert Bellah referred to as the "new consciousness" (Glock and Bellah 1976).${ }^{15}$ As the author Peter Richardson said, it was really about three things: "transcendence, ecstasy, and community," all of which he viewed as elements of spirituality (interview, 11 August 2014). According to Richardson, the Grateful Dead epitomized these movements, and as he argued, "I really don't think you can understand their success without placing it against [the] Back to the Land movement ... which is environmental, and it's sort of nostalgic in some way" (interview, 11 August 2014). ${ }^{16}$ The Back to the Land movement was (and is) a movement which attempts a return to an simpler, agrarian ways of life which some of these early countercultural movements attempted to rediscover (see (Gould 2005) for a discussion of its religious dimensions).

\section{Ethnographic and Survey Data}

There is a robust literature on the emergence of these movements, and specifically the centrality of music scenes to their development. Social scientists and humanities scholars have examined the social, economic, and spiritual dimensions of these movements for decades, with the Grateful Dead receiving the most scholarly attention (Adams and Sardiello 2000; Sutton 2000; Hartley 2000; Richardson 2015). Other scholars have expanded such rumination to other musical forms, such as psy-trance, electronic music, and to the religious dimensions of festival scenes (St. John 2008, 2010, 2012; Gilmore 2010), but the contemporary manifestations of the jamband scene have been relatively under-examined (for exceptions see Szatmary [1987] 2007, pp. 145-201; Till 2010).

My first jamband show was in 1994, and in the intervening 24 years I have participated in hundreds of shows and festivals which informed this research. I first began collecting ethnographic data in 2005 as I began to formulate research questions. Formal in-depth interviews of movement

15 Glock and the sociologist Robert Bellah organized a large-scale study, putting their graduate students to work exploring the contours of this new consciousness in the Bay Area. Bellah was a professor at the University of California, Berkeley, while Glock taught at the nearby Graduate Theological Union (GTU).

16 Stewart Brand, who was one of the Merry Pranksters, also started the Whole Earth Catalog (http:/ / www.wholeearth.com/ history-whole-earth-catalog.php, accessed on 27 August 2018), a well-known publication which was essentially about getting back to the land and getting off the grid, much of what would today fall under the umbrella of the Lifestyles of Health and Sustainability (LOHAS) marketing paradigm (see Emerich 2014). 
intellectuals and contributors, along with deployment of the survey instrument began in $2013 .{ }^{17} \mathrm{I}$ pre-tested two versions of the survey instrument in 2013 and 2014, and finalized the survey in the summer of 2014. From 2014 to 2015 I distributed the survey electronically through various social media outlets related to specific bands and their fans, and also distributed some paper surveys at concerts and festivals. ${ }^{18}$

The short narrative about the artist the Polish Ambassador above recalled that "friends, family, and extended tribe made their way around the table and dance floor: smiles beaming, hearts bursting open, tears welling up, people dancing their prayers." This sort of highly affective description is not unusual among the individuals and groups I have encountered. This data illustrated a few important facts: (1) jamband fans self-report relatively high levels of environmental and social awareness; (2) such awareness is grounded in either cosmological, biological, or interpersonal metaphors of relationality; (3) most of those in this cohort consider themselves to be spiritual but not religious; and (4) there are significant numbers of this subculture who connect this music and the festival scenes with which it is associated with their spirituality. A large majority of the sample population were raised in what they perceived to be Christian homes, and yet significant proportions of them no longer considered themselves to be religious. Moreover, large proportions of those who no longer considered themselves to be religious often found spiritual fulfillment or lessons within the jamband scene. These findings indicate that there are significant, if under scrutinized, cosmophilic, biophilic affinities related to Darwinian understandings of evolutionary kinship, and to close and intense interpersonal exchange in these groups, which are cast in spiritualized terms and tropes. Questions remain about whether this is correlated with the numbers of (particularly younger) people who are disaffected from traditional religions. But it does indicate that some are seeking atypical modes of meaning making, and are in some cases actively resisted, by traditional sources of religious authority. ${ }^{19}$

Such experiences were often discussed in terms that the anthropologist Michael Winkleman (2009) referred to as "integrative" modes of consciousness, where participants may attribute such integration to cosmological, biophysical, or social (interpersonal) connections. When asked whether they grew up in a religious home, a spiritual home, or neither, $61 \%$ of the respondents reported that they grew up in a religious home, close to $11 \%$ reported that they grew up in a household that was "spiritual," while $28 \%$ (in the USA, slightly more than the general populace) reported that they grew up in neither a religious or spiritual home. Of those who reported that they grew up in a religious home, an overwhelming majority reported having a Christian upbringing $(92 \%)$, with those raised in Jewish households making up the second largest category $(9 \%) .{ }^{20}$ When asked whether they were religious, spiritual, or neither today, only about $17 \%$ of respondents reported being religious, while $56 \%$ reported identifying as spiritual, and $27 \%$

17 The study was filed with the IRB office at Wake Forest University (WFU IRB: 00021450). This was not a representative sample: respondents were not randomly selected, but rather self-selected to complete the surveys from a good cross-section of the scene's most important bands. Respondents were not required to complete all questions to participate in the survey, thus the different subject numbers for different questions. The online dissemination is necessarily somewhat restrictive. I gathered ethnographic data from respondents/fans who favored bands from the Southeastern U.S., the Northeastern U.S., and from the West Coast, the areas in which the jamband scene is most active.

18 Distributing surveys in person at festival events presented significant challenges. First, because illicit drugs and often alcohol are for many participants important elements of the scene, some lacked either the attention span or the desire to engage in extended conversation, or fill out a survey. Second, because of the sometimes heavy use of entheogens, alcohol, and other psychotropic substances, there are typically both uniformed and undercover law enforcement officials present, and thus a natural suspicion of divulging what some perceive is personal information (even if there was no identifying information on the survey). Online surveys were distributed through social media sites and official sites related to some of the most well-known contemporary bands in the scene, such as Phish, Widespread Panic, The Allman Brothers, and Gov't Mule. Ethnographic data was collected at many specific concert events, primary in the Southeastern US, and at select festivals, such as Lock'n (Arrington, VA), and Outside Lands (San Francisco, CA).

19 For instance, organizations such as the Cornwall Alliance, and Answers in Genesis seek to cast moralistic affinities for the universe, and other-than-human creatures as potentially pernicious animistic or pagan sentiments, and generate advertising campaigns and curricular materials to resist what they perceive is a dangerous secular movement.

20 The respondents did differentiate between Catholic or Protestant in orientation. Such nuances are important, but perhaps not to the case that I wish to make here. 
reported no affiliation or affinity with religion or spirituality $(n=639)$. In particular, $53 \%$ of those who identified as growing up Christian now identify as "spiritual," and not identified with Christianity.

One responded reported that "my religion is music," while another stated that they were "less church driven, more belief in a higher power." This phenomena was also evident in the ethnographic data collection: this sample contained a tremendous number of people who were once religious (mostly Christian), and who found spiritual fulfillment elsewhere. As one respondent put it, "the way I was raised and the way I am now are two things. Was raised Christian but never went to church. I now find spirituality in nature." Or as another said, "We went to many different churches growing up. None of them stuck. Now I consider myself 'going to church' when I'm hiking in the woods, paddling my kayak, swimming in the ocean or dancing under the stars!" Expressing a sort of cosmophilic sentiment, one opined that "[was] raised Methodist, [but I] don't believe in organized religion as a force for good, [I] adopt a Buddhist viewpoint of the world but consider it a philosophy[.] I don't believe in belief."

Tellingly, only $2 \%$ of respondents reported that the jamband scene informs their religious orientation. Meanwhile, a significant number, $45 \%$ of survey participants, suggested that the jamband scene informs their spiritual orientation. Many (approximately 38\%) indicated that the jamband scene and their religious or spiritual sensibilities were not related at all, but significant proportions of the respondents reported such a relation. Moreover, approximately one quarter $(26 \%)$ of the respondents reported that they belonged to or support an environmental organization $(n=698)$. Much more significant numbers, however $(88 \%)$, reported a perception that jamband fans were environmentally aware or conscious $(n=711)$.

Spiritual tropes are nearly always couched in some sort of relationality. One way such it may manifest is in what I have elsewhere (Johnston 2010) referred to as a sense of cosmophilia-a perception that one is connected to some universal force or purpose (although perceptions of whether such forces are personal or impersonal may vary). Or, it may manifest in articulations of interconnectedness to other-than-human creatures, or even places which are imagined as having significance (Noel 2004). Finally, there may be an important interpersonal dimension, which focuses on the construction of human communities through participation in such festival scenes. It is important to note that among participants in the scene, there is often some overlap in these three modes of relationality. Although much research in the human sciences is premised on the assumption that humans are bounded, discreet, cost-benefit calculating individuals, in reality humans are radically relational, trafficking in communities from the local to the global, and from the interpersonal to the cosmological. These are what I have called "communities of accountability" - the various communities at different scales to which people are beholden to various degrees.

To illustrate I ruminate on whether such cosmophilic articulations, or biologically- and interpersonally-oriented modes of belongingness are parallel with, or could be fruitfully analyzed through the five-fold definition of worldviews. To unpack responses that indicated some sort of cosmophilic affinities, when asked about their religious and spiritual lives, one respondent reported that "[I] believe in nature," while another reported that "[I] now find my spirituality in nature." One respondent noted that "Spirituality absolutely came to me through my interactions with nature, with people, and most definitely through the jam band scene and also mind-altering substances. I believe in the universe and energies ... I've experienced it." This illustrates both a "belief" in cosmic energies or forces, but also evidences the ways in which they are often entangled with the biological and interpersonal categories that I have offered here. With a similar sentiment, another respondent reported that "we are all one energy in the universe. We have trouble with that concept due to our human form. Matter cannot be created nor destroyed, it only changes forms so the energy remaining in our bodies when we die must change forms back to our spirit/soul and return to the cosmos. Karma is most definitely real and the spirit moves thru [sic] all things and sees all things so be good and stay human."

These are representative statements that roughly articulate or approximate many of my interlocutors' perceptions. Others commented: "I don't believe in structured religion. I believe in a higher power ... Mother Nature controls the universe"; and "religion can be a comfort to some, although it predominantly separates us from one another ... spirituality is a oneness with one another, 
the earth, the universe, and all that is included within." Another wrote, "Now I believe in the power of the universe around us." Recently, the band Phish played 13 days at Madison Square Garden, an experience that was billed as the "Baker's Dozen," with each night correlated with a specific type of donut - a sort of theme for the evening. Several new cover songs related to each night's theme donut were debuted. On one of the nights, the guitarist (Trey Anastasio) and bassist (Mike Gordon) sat down in chairs and staged a conversation based on a 2003 article about astrophysics (Overbye 2003), in which the author recounted theoretical work which suggested that the topography of the universe may well be like a donut, in astrophysical terms, finite, but unbounded. Clearly, such antics are meant to reverse the often-presumed seriousness of religion, to "play" with the received categories in ways that are fun, but which also challenge the ways in which cosmologies inform moral sensibilities. References to this event are, at this writing, still ubiquitous on fan boards and social media sites.

To attempt some assessment of the range of ethical perceptions of the non-human world (from anthropocentric to eco-centric), I adapted some of the criteria developed by the ecologist Stephen Kellert (Kellert and Wilson 1993) to explore the biologist Edward O. Wilson's biophilia hypothesis (Wilson 1984). ${ }^{21}$ Large proportions of the sample $(n=695)$ assented to the phrase "The environment can be used for human benefit, but humans also have responsibility to protect and care for it" (73\%). This is a somewhat anthropocentric perspective, but also indicates some sort of altruism toward the natural world. Two statements referred to some aesthetic value of nature, which may of course manifest in either anthropocentric or more biocentric orientations. For instance $75 \%$ resonated with the statement that: "For me nature has physical appeal, or is considered beautiful," and $62 \%$ with the idea that "The natural world is valuable because I derive some satisfaction from direct experience/contact with nature."

The most strongly Darwinian perspective included in the typology received relatively strong support: "The natural world is important as a subject of scientific study; understanding the structure, function and relationships in nature are valuable" (nearly 70\%). Two additional statements cluster as strongly biophilic sensibilities, and also indicate that significant numbers of participants do consider nature to have spiritual and/or ethical significance. The first, "I have a strong affinity, spiritual reverence, or ethical concern for nature" (58\%), the second, "The natural world is valuable because I have strong emotional attachment, or 'love' for it" (56\%) both received strong support.

There is one category which is clearly bio- or eco-centric in its ethical orientation: "There is no such thing as an "environment" separate from humans-human and environmental well-being are one," to which $25 \%$ of respondents assented. It received somewhat less support than the others, but that fully one quarter of participants assented to such a claim is fascinating, and as noted, more research is needed to discern whether it might be correlated with the rising numbers of people who feel disaffected from the institutionalized religions of the world, and seek spiritual fulfillment elsewhere. ${ }^{22}$

The social or interpersonal category is the third area in which a spiritually-grounded sense of relationship to others is evidenced. Among my sample, $92 \%$ reported that their perception is that jamband fans have a sense of social awareness or conscience $(n=728)$, while around a quarter of them report that they belong to or support a community advocacy, social justice, or social service organization $(n=704)$. One individual who reported that they were spiritual, but not religious, suggested that they "became an adult and realized religion is complete bullshit," and that they find their spiritual fulfillment among the jamband scene. Another reported: "I am a born again non-Christian. I believed in Christ ... as a kid, but I've grown into a disbeliever. Now, I consider myself a spiritual person, but it is more along the lines of being interconnected with humanity and the earth." Here, once again,

21 Simply put, the biophilia hypothesis suggests that all life exhibits certain affinities for other carbon-based life. I conducted a pilot study utilizing Kellert's typology at the University of Florida in 2005, which informed this usage.

22 See for example the study by the Pew Charitable Trust from 2012, http:/ / www.pewforum.org/2012/10/09/nones-on-the-rise/, and ubiquitous press coverage, including The Christian Examiner, http:/ / www.christianexaminer.com/article/nones.are.largest. religious.group.in.23.states.maybe/48466.htm, and the National Catholic Reporter, https:/ / www.ncronline.org/blogs/ncrtoday/rise-nones-or-nons, all accessed on 1 August 2017. 
it is possible to note that these categories are not mutually exclusive. The sentiment expressed here, that spiritual sensibilities extend both to special human communities, and to "the earth," indicate that people may express spiritual affinities in multiple ways, and perceive them to be important in multiple communities of accountability.

\section{Discussion and a Look Ahead}

As a comparative thought experiment, can we arrange the revised elements of a worldview to correspond with the perceptions, behaviors, and predispositions of those in the jamband scene? If so, what would it tell us about the utility of rescuing the worldview concept as an analytical tool?

In my subfield the worldview concept has played a prominent role. But the supposition that rationalized ideas are the causal factor in particular behaviors is suspect. Rather, highly affective experiences (integrative modes of consciousness, or particularly poignant "flashbulb" experiences) are often formative for normative presuppositions and the cosmological imagination. For instance, in many cases my interlocutors' ideas about the interconnectedness of nature, or indeed of the cosmos, was facilitated by profound experiences of fellow-feeling and belongingness derived from a musically-inspired sense of communitas. This, according to many participants, is what is "real" - many occupy "flow-resistant" jobs which provide no affective fulfillment. Their "real" selves come out when it is festival time, or when they can break away from their routine for a concert. The social media landscape (and memescape) has literally thousands of references to occupations as nothing more than vehicle for purchasing summer concert tickets. Often, travel to shows or festivals is described as a sort of pilgrimage to a "sermon" or other religious event (Johnston 2016a). In this case, it seems that the experience of belongingness becomes normative, providing interpersonal experiments grounded in reciprocation and participation that determine what sorts of experiences are meaningful, or "real." In this, we might imagine that the "axiological dimension" informs the epistemological dimension (an ethics-based epistemology), which in turn informs cosmogonic and/or cosmophilic sensibilities, which are subsidiary to those experiences. In this case, ontology, that is, what is "real," comes cheap-it may be a donut (maybe not), but it is conditioned by ethically-salient experiences. It may be possible to render the worldview elaborated here in the following way: axiology $\rightarrow$ epistemology $\rightarrow$ cosmology $\rightarrow$ praxeology $\rightarrow$ ontology (see Figure 2). But what is missing is the strongly experiential dimension which underlies the axiological. The ways in which my interlocutors describe such experience is not captured by this more cognitively-oriented category "axiology," particularly when it is compared to the "axiological" orientation of, say, interfaith organizations.

Attending to the elements of worldviews that particular constituencies or individuals find most important or compelling might provide a rough heuristic for how to do comparative work without recapitulating some of worst crimes of the academy (Johnston 2016b). When it came to analysis of sustainability-oriented social movements, I imagined that "religion" was a good umbrella term for everything that was either "spiritual," or more overtly religious. Given that I had defined the category so broadly, I felt that even those who self-identified as "spiritual" would fall under the umbrella of "religion." But many within the jamband scene explicitly drew a distinction between religion and spirituality. Despite J.Z. Smith's admonition that bounding the term is the scholar of religions' primary stock-in-trade, in some cases it may be more productive to utilize a concept such as worldview, which has elements which may be relatively ubiquitous, but which may be prioritized or highlighted in different ways by different individuals, groups, and movements. However, importantly, people who identify as "spiritual but not religious," or "none of the above," are not rejecting scholars' attempts to bound the term broadly. Rather, they are rejecting what they perceive to be a brand of identity politics specific to Christians, and specifically evangelical communities in North America. Many of those who remain spiritual but not religious perceive religion to be identified with institutional hierarchies, anti-science bias, and other pre-experiential commitments which do not accord with the experiences of fellow feeling (whether cosmological, biological, or interpersonal) described here. In other words, some have staked out non-religious identities precisely because they wish to distance themselves 
(often publicly) from what they perceive to be pernicious and exclusive understandings prevalent in culture (i.e., evangelicals who wish to preserve the right to refuse services to people with whom they disagree religiously) (Veldman et al. 2014).

\begin{tabular}{|l|l|l|l|}
\hline \multicolumn{1}{|c|}{ Religious } & \multicolumn{1}{|c|}{ Interfaith } & \multicolumn{1}{c|}{ Secular } & \multicolumn{1}{c|}{ Jamband Subcultures } \\
\hline $\begin{array}{l}\text { (5) Cosmology- } \\
\text { theocentric }\end{array}$ & $\begin{array}{l}\text { (3) Axiology-conversation } \\
\text { and dialogue; common } \\
\text { ground }\end{array}$ & $\begin{array}{l}\text { (4) Praxeology-we have } \\
\text { the science, we need } \\
\text { people to enact what we } \\
\text { know will work }\end{array}$ & $\begin{array}{l}\text { (3) Axiology- } \\
\text { grounded in } \\
\text { experiences of fellow- } \\
\text { feeling }\end{array}$ \\
\hline $\begin{array}{l}\text { (1) Ontology-theology } \\
\text { of dependence/Western } \\
\text { conceptions of } \\
\text { spirit/matter dualism }\end{array}$ & $\begin{array}{l}\text { (4) Praxeology-what } \\
\text { should be done with this } \\
\text { common denominator of } \\
\text { ethical understanding? }\end{array}$ & $\begin{array}{l}\text { (3) Axiology-any ethical } \\
\text { stance will concur on } \\
\text { basic principles of what } \\
\text { to do: virtue ethics; } \\
\text { deontological ethics; } \\
\text { utilitarian ethics }\end{array}$ & $\begin{array}{l}\text { (2) Epistemology- } \\
\text { what's "real," what's } \\
\text { important in life? }\end{array}$ \\
\hline $\begin{array}{l}\text { (2) Biblical cosmology, } \\
\text { which illustrates } \\
\text { human dependence on } \\
\text { Creator }\end{array}$ & $\begin{array}{l}\text { (5) Common past (i.e., } \\
\text { universe story/big bang) }\end{array}$ & $\begin{array}{l}\text { (1) Ontology-the } \\
\text { problems we face (as a } \\
\text { species, or society) are } \\
\text { real }\end{array}$ & $\begin{array}{l}\text { (5) Cosmology- } \\
\text { evident in cosmophilic } \\
\text { statements and } \\
\text { perceptions }\end{array}$ \\
\hline $\begin{array}{l}\text { (3) Epistemology-the } \\
\text { scriptures spell out the } \\
\text { theological human } \\
\text { exceptionalism }\end{array}$ & $\begin{array}{l}\text { (3) Ontolog-the cosmos or } \\
\text { earth as the ground of } \\
\text { being-what's important }\end{array}$ & $\begin{array}{l}\text { (4) Epistemology-in } \\
\text { many cases secular } \\
\text { organizations can work } \\
\text { with local (indigenous) } \\
\text { knowledge }\end{array}$ & $\begin{array}{l}\text { (4) Praxeology- } \\
\text { treating others well, } \\
\text { participating in } \\
\text { community }\end{array}$ \\
\hline $\begin{array}{l}\text { (4) Praxeology-varies } \\
\text { by interpretation }\end{array}$ & $\begin{array}{l}\text { (2) Epistemology- } \\
\text { allowing for indigenous } \\
\text { and other lifeways, but } \\
\text { what is important is } \\
\text { common ground }\end{array}$ & $\begin{array}{l}\text { (5) Cosmology-there are } \\
\text { many which can lead to } \\
\text { the axiological/ } \\
\text { praxeological elements } \\
\text { above }\end{array}$ & $\begin{array}{l}\text { (1) Ontology- } \\
\text { seemingly little } \\
\text { consideration of this } \\
\text { element, or if so, } \\
\text { couched in } \\
\text { cosmological or } \\
\text { relational terms }\end{array}$ \\
\hline
\end{tabular}

Figure 2. Sustainability-oriented worldviews compared with jamband scene worldviews.

Others who are outside the typically religious mainstream in North America, by contrast, wish to be considered to be authentically religious precisely so that they can compete with such exclusivist understandings of the category. For instance, Satanist churches have often brought suit against townships for public demonstrations of Christian nativity scenes, or public displays of the Ten Commandments of the Hebrew Bible. In such cases, they argue that their religious perceptions and beliefs ought to be given a fair hearing. Indeed, even authentically fake religions, such as Pastafarianism (the religion of the Flying Spaghetti Monster) do important religious work (Van Horn and Johnston 2007). So in some cases, particularly cases in which there is an attempt to compare the religious dimensions of non-religious cultural phenomena, the worldview concept may be advantageous. But in the end it is unclear whether it is enough of an advantage to reject terms such as "religion" because of these few cases. In some cases the notion of "ways of life" may be more helpful than worldviews, but ways of life is so broad that it risks losing any meaning when deployed by western ethnographers who have in mind a notion that behaviors are driven by ideation or cognized values. Some scholars who investigate indigenous groups have employed the terms "lifeways," or "life projects" related to their own attempts to assert or maintain native sovereignty in the face of development and globalization (Blaser et al. 2004). Such terms self-consciously avoid or resist the ethnocentric notion that ideas and ideals have primacy over behaviors and practices, and to the extent that they describe an ethics-based epistemology (Cheney and Weston 1993) they may avoid some of 
the problems inherent in deploying both worldviews and religion as important categories for studying human cultural production. But my suspicion is that such a term would require careful definition and elaboration to be broadly useful.

To sum up, then, first, all invocations of religions, worldviews, or lifeways are contested, and thus, political. Second, the category "religion" may certainly include the five elements of a worldview elaborated here. So in some cases, it is unclear what is to be gained by the invocation of worldviews over the exercise of an expansive definition of religion. Third, if non-religious phenomena, or those which are implicitly religious are the focus, they are defined as such at least tacitly with reference to some unspoken referent "religious," which perhaps mystifies as much as it clarifies, unless a prototype of such a category is specified (which, again, begs questions about the social location of that prototype). Finally, although the five-fold typology of worldviews attempts to correct ethnocentric understandings of the term, it still seems to privilege cognized "representations" at the expense of the sorts of ritual and communitas that lie behind any invocations of "praxeology" or "axiology." The expense of exercising a worldviews model may well be the inability to sufficiently account for the deeply affective and embodied perceptions of belongingness and fellow-feeling which are formative for many, for instance among the jamband scene introduced here. If the terms "ways of life" or "lifeways" was utilized instead to describe such cultural production, it would necessarily need to differentiate between occupational "life," and what many in the jamband perceive as their "real" lives at concerts or festivals. ${ }^{23}$ Are such intermittent, and transitory experiences adequately captured by terms such as "lifeways"? Again, more specificity with such terms may be helpful.

I have here tried to summarize some of my research and conduct a sort of thought experiment by comparing worldviews based on ethnographic evidence. Discerning individuals' and groups' primary communities of accountability, and their primary normative referents (i.e., are they cosmological, axiological, praxiological, ontological, or epistemological?), may be a productive way to imagine a sort of comparative ethnographic context for scholarly work. In this case, then, the elements of the five-fold typology of a "worldview" may themselves be the data for empirical analysis. But to refer to worldviews as "a complex set of representations related to 'big questions,'" with an eye to study "religion-like" groups, (1) casts worldviews as mental maps (representations); (2) begs the question of what might be the prototype for "religion"; and (3) seems to paper over the always contested cultural terrain in which such definitions take shape. Without further elaboration, it is unclear what such a category might offer to ethnographers that succeeds in ways that explicit heuristic definitions of religion cannot.

Acknowledgments: I am grateful to Robin Globus Veldman and Bernard D. Zaleha, who offered helpful comments on the first drafts of this paper. The research related to jambands also benefitted from funds provided by the Ollen R. Nalley Family Faculty Fellowship, and the Wake Forest Center for Energy, Environment, and Sustainability (CEES).

Conflicts of Interest: The author declares no conflicts of interest.

\section{References}

Adams, Rebecca G., and Robert Sardiello. 2000. Deadhead Social Science: You Ain't Gonna Learn What You Don't Want to Know. Walnut Creek: Alta Mira.

Arnal, William, and Russell McCutcheon. 2013. The Sacred Is the Profane: The Political Nature of "Religion. New York: Oxford University Press.

Budnick, Dean. 2003. Jamband: The Complete Guide to the Players, Music, E Scene. San Francicsco: Backbeat Books. Callicott, J. Baird. 1994. Earth's Insights: A Multicultural Survey of Ecological Ethics from the Mediterranean Basin to the Australian Outback. Berkeley: University of California Press.

23 Indeed, such distinctions might also require rumination on the emergence of "leisure" among late capitalist societies, and how it relates to spiritual experience, practice, and doctrine (see Turner 1982; St. John 2008). 
Chapple, Christopher Key. 2000. Hinduism and Ecology: The Intersection of Earth, Sky, and Water. Cambridge: Harvard University Press.

Chapple, Christopher Key. 2002. Jainism and Ecology: Nonviolence in the Web of Life. Cambridge: Harvard University Press. Chidester, David. 2005. Authentic Fakes: Religion and Popular Culture in America. Berkeley: University of California Press. Connors, Peter. 2013. JAMerica: The History of the Jam Band and Festival Scene. Philadelphia: Da Capo.

Dubuisson, Daniel. 2003. The Western Construction of Religion: Myths, Knowledge, and Ideology. Baltimore: Johns Hopkins University Press.

Eliade, Mircea. 1959. The Sacred and the Profane: The Nature of Religion. New York: Harcourt.

Emerich, Monica. 2014. The Gospel of Sustainability: Media, Market, and LOHAS. Urbana: University of Illinois Press.

Foltz, Richard, Frederick Mathewson Denny, and Azizan Haji Baharuddin. 2003. Islam and Ecology: A Bestowed Trust. Cambridge: Center for the Study of World Religions, Harvard Divinity School, Distributed by Harvard University Press.

Gilmore, Lee. 2010. Theater in a Crowded Fire: Ritual and Spirituality at Burning Man. Berkeley: University of California Press.

Glock, Charles Y., and Robert N. Bellah. 1976. The New Religious Consciousness. Berkeley: University of California Press.

Gould, Rebecca. 2005. At Home in Nature: Modern Homesteading and Spirital Practice in America. Berkeley: University of California Press.

Grim, John. 2001. Indigenous Traditions and Ecology: The Interbeing of Cosmology and Community. Cambridge: Harvard Press for the Center for the Study of World Religions, Harvard Divinity School.

Hand, Floyd. 1998. Looks for Buffalo. In Learning Journey on the Red Road. N.p.: Learning Journey Communications. Hartley, Jennifer A. 2000. 'We Were Given this Dance': Music and Meaning in the Early Unlimited Devotion Family. In Deadhead Social Science: You Ain't Gonna Learn What You Don't Want to Know. Walnut Creek: Alta Mira, pp. 129-54.

Harvey, Graham. 2013. Food, Sex and Strangers: Understanding Religion as Everyday Life. Stocksfield: Acumen Pub.

Hawken, Paul. 2007. Blessed Unrest: How the Largest Movement in the World Came Into Being, and Why NO One Saw It Coming. New York: Viking Press.

Hessel, Dieter T., and Rosemary Radford Ruether. 2000. Christianity and Ecology: Seeking the Well-Being of Earth and Humans. Cambridge: Harvard University Press for the Harvard University Center for the Study of World Religions.

James, William. 2002. The Varieties of Religious Experience. London: Routledge. First published in 1902.

Johnson, Mark. 1993. Moral Imagination: Implications of Cognitive Science for Ethics. Chicago: University of Chicago Press.

Johnston, Lucas F. 2010. From Biophilia to Cosmophilia: The Role of Biological and Physical Sciences in Promoting Sustainability Healing. Journal for the Study of Religion Nature and Culture 4: 7-23. [CrossRef]

Johnston, Lucas F. 2013. Religion and Sustainability: Social Movements and the Politics of the Environment. Sheffield and Bristol: Equinox.

Johnston, Lucas F. 2014. Sustainability as a Global Faith? The Religious Dimensions of Sustainability and Personal Risk. Journal of the American Academy of Religion 82: 47-69. [CrossRef]

Johnston, Lucas F. 2016a. Dancing My Prayers: Material Culture and Spiritual Practices of Improvisational Rock Music Subcultures. In Practical Spiritualities in the Media Age. New York: Bloomsbury Press.

Johnston, Lucas F. 2016b. Cultivating an Academy We Can Live With: The Humanities and Education for Sustainability. Religions 7: 120. [CrossRef]

Johnston, Lucas F., and Bron Taylor. 2016. Religion and Environmental Politics into the Twenty-First Century and Beyond. In The Wiley Blackwell Companion to Politics and Religion in America. West Sussex: Wiley Blackwell.

Johnston, Lucas, and Robert Wall. 2014. The Camel and the Eye of the Needle: Religion, Moral Exchange, and Social Impacts. In The Changing World Religions Map. Edited by Stanley Brunn. New York: Springer.

Kellert, Stephen, and E. O. Wilson, eds. 1993. The Biophilia Hypothesis. Washington: Island Press.

Lovejoy, Thomas. 2002. Biodiversity: Threats and Challenges. In Biodiversity, Sustainability, and Human Communities: Protecting Beyond the Protected. Edited by Timothy O'Riordan and Susanne Stoll-Kleeman. Cambridge: Cambridge University Press.

Müller, Max. 2002. The Science of Religion. In The Essential Max Müller: Language, Mythology, and Religion. Edited by J.R. Stone. New York: Palgrave Macmillan. First published in 1870.

Norton, Bryan. 1994. Toward Unity Among Environmentalists. New York: Oxford University Press.

Overbye, Dennis. 2003. Universe as a Doughnut: New Data, New Debate. New York Times, March 11, sec. Science. 
Patten, Chris, ed. 2000. Respect for the Earth: Sustainable Development. London: Profile Books.

Pigem, Jordi. 2007. Faith-Based Organizations and Education for Sustainability. In Report of the Internatinoal Experts' Workshop. Barcelona: Centre UNESCO de Catalunya, pp. 22-24.

Richardson, Peter. 2015. No Simple Highway: A Cultural History of the Grateful Dead. New York: St. Martin's Press.

Saler, Benson. 1993. Conceptualizing Religion: Immanent Anthropologists, Transcendent Natives, and Unbounded Categories. Leiden and New York: E.J. Brill.

Saler, Benson. 2004. Toward a Realistic and Relevant "Science of Religion". Method and Theory in the Study of Religion 16: 205-33. [CrossRef]

Smart, Ninian. 2008. The World's Religions. New York: Cambridge University Press.

Smith, Jonathan Z. 1982. Imagining Religion: From Babylon to Jonestown. Chicago: University of Chicago Press.

St. John, Graham. 2008. Victor Turner and Contemporary Cultural Performance. New York: Berghahn Books.

St. John, Graham. 2010. The Local Scenes and Global Culture of Psytrance. New York: Routledge.

St. John, Graham. 2012. Global Tribe: Technology, Spirituality, and Psytrance. Sheffield: Equinox.

Sumner, Jennifer. 2005. Sustainability and the Global Commons: Rural Communities in the Age of Globalization. Toronto: University of Toronto Press.

Sutton, Shan. C. 2000. The Deadhead Community: Popular Religion in Contemporary American Culture. In Deadhead Social Science: You Ain't Gonna Learn What You Don't Want to Know. Walnut Creek: Alta Mira, pp. 109-27.

Szatmary, David P. 2007. Rockin' in Time: A Social History of Rock-and-Roll. Upper Saddle River: Pearson Prentice Hall. First published 1987. First published 1987.

Taves, Ann. 2009. Religious Experience Reconsidered: A Building Block Approach to the Study of Religion and Other Special Things. Princeton: Princeton University Press.

Taylor, Bron Raymond. 2010. Dark Green Religion: Nature Spirituality and the Planetary Future. Berkeley: University of California Press.

Taylor, Bron Raymond. 2002. Diggers, Wolves, Ents, Elves and Expanding Universes: Bricolage, Religion, and Violence from Earth First! And the Earth Liberation Front to the Antiglobalization Resistance. In The Cultic Milieu: Oppositional Subcultures in an Age of Globalization. Edited by Jeffrey Kaplan and Helen Loow. Walnut Creek: Alta Mira Press, pp. 26-74.

Till, Rupert. 2010. Pop Cult: Religion and Popular Music. London: Continuum.

Tirosh-Samuelson, Hava. 2002. Judaism and Ecology: Created World and Revealed Word. Cambridge: Harvard University Press for the Center for the Study of World Religions, Harvard Divinity School.

Tucker, Mary Evelyn, and Duncan Ryūken Williams. 1997. Buddhism and Ecology: The Interconnection of Dharma and Deeds. Cambridge: Harvard University Center for the Study of World Religions, Harvard University Press.

Tucker, Mary Evelyn, and John H. Berthrong. 1998. Confucianism and Ecology: The Interrelation of Heaven, Earth, and Humans. Cambridge: Distributed by Harvard University Press for the Harvard University Center for the Study of World Religions.

Turner, Victor. 1982. From Ritual to Theater: The Human Seriousness of Play. New York: Performing Arts Journal Publications.

Van Horn, Gavin, and Lucas F. Johnston. 2007. Evolutionary Controversy and a Side of Pasta: The Flying Spaghetti Monster and the Subversive Function of Religious Parody. Golem: Journal of Religion and Monsters 1: 1-32.

Veldman, Robin Globus, Andrew Szasz, and Randolph Haluza-DeLay. 2014. How the World's Religions are Responding to Climate Change: Social Scientific Investigations. New York: Abingdon Press.

Von Stuckrad, Kocku. 2007. Finding Data: Some Reflections on Ontologies and Normativities. Journal for the Study of Religion, Nature E Culture 1: 39-46.

WCED (World Commission on Environment and Development). 1987. Our Common Future. Oxford: Oxford University Press.

Winkleman, Michael. 2009. Shamanism and the Origin of Spirituality and Ritual Healing. Journal for the Study of Religion, Nature E Culture 3: 458-89.

Wittgenstein, Ludwig. 1968. Philosophical Investigations, 3rd ed.Oxford: Blackwell.

(C) 2018 by the author. Licensee MDPI, Basel, Switzerland. This article is an open access article distributed under the terms and conditions of the Creative Commons Attribution (CC BY) license (http:/ / creativecommons.org/licenses/by/4.0/). 